\title{
Environmental Performance Evaluation of Latin American Industries by Using the Industrial Solid Waste Destination Index (ISWDI)
}

\author{
Hosmanny Mauro Goulart Coelho, Liséte Celina Lange, Lineker Max Goulart Coelho, and Matheus \\ Rennó Sartori
}

\begin{abstract}
This research consists in to present the application of the Industrial Solid Waste Disposal Index (ISWDI), that is formed by 7 sub-indexes covering 20 indicators, involving the principles of non-generation, minimization, reuse, recycling, treatment, storage and final disposal. The benchmark that guided the evaluations of ISWDI was obtained from environmental reports, auditable documents and technical visits in the automotive industry textile, cement, power, dairy products and steel industries. The ISWDI developed was simulated from real data and has demonstrated its applicability in the Brazilian reality. Thus, this paper intends to expand the use of the index for Latin America. So, we intend to prove its efficiency in management assessment and to support decision making managers. This analysis was done by comparing the results obtained by the simulation of a Brazilian and a Chilean company, both from the pulp and paper industry. The results proved the efficiency of the model and the compatibility of the expected evaluations. Thus, the ISWDI constitutes a management tool applicable to the reality of Latin America.
\end{abstract}

Index Terms-Index, industrial waste, environmental performance, waste management.

\section{INTRODUCTION}

The high level of consumption and, consequently, accelerated industrial development observed in various parts of the world has led to increase generation of industrial solid waste. According to [1] about 1.3 billion tonnes of solid waste are generated annually, and it estimated that this amount will increase to 2.2 billion tonnes by 2025 .

At the same time, waste management has gained importance because the solid waste disposal generates several impacts to the environment. Thus, it becomes necessary to find ways to reverse this situation. In a general framework, to minimize this impacts firstly is necessary the establishment of environmental quality standards to be followed.

In addition, waste management is a method directing

Manuscript received May 30, 2014; revised July 31, 2014. This work was supported in part by the National Council for Scientific and Technological Development $(\mathrm{CNPq})$, Ministry of Science and Technology, Brazilian Government.

Hosmanny Mauro Goulart Coelho and Liséte Celina Lange are with Federal University of Minas Gerais, School of Engineering, Department of Sanitary and Environmental Engineering - Bloco 2 - Sala 4628 - Av. Antônio Carlos, 6627 - Pampulha - Belo Horizonte - Minas Gerais - CEP 30.270-901 - Brazil (e-mail: hosmanny@hotmail.com, lisete@desa.ufmg.br).

Lineker Max Goulart Coelho and Matheus Rennó Sartori are with École des Ponts ParisTech 6 et 8 avenue Blaise-Pascal - Cité Descartes Champs-sur-Marne, 77455, Marne-la-Vallée, France. managements and/or institutions to acting for sustainability by displaying their ability to use and protect current resources [2], [3].

Furthermore, sustainable development means a balance between economic efficiency, social equity and environmental protection. Moreover the first definition of this term provided by the World Commission on Environment and Development (WCED) in 1991, sustainable development consists in a "development that meets the needs of the present without compromising the ability of future generations to meet their own needs" [4].

So, the SWM has a crucial role to achieve this condition, because when its steps are executed properly they contribute to reducing environmental liabilities and decreasing natural resources requirements including fossil fuels and water.

It's important to note that the disposal should obey the classic hierarchy principle of the solid waste management, which is organized by priority order, which starts from the non-generation and ends up in the final disposal. Between these steps, there are respectively: the minimization of waste generation, reuse, recycling and treatment (in the present work, minimization of waste generation is considered a sort of destination).

According to [5], the main goal of technologies and policies for solid waste management (SWM) is to protect the environment and human health by reducing the negative impacts of waste and looking for ways to reuse them to provide benefits to society.

Several studies have presented the benefits from waste management to sustainability. Reference [6] has reported the contribution of MSW to sustainable development in Germany. Reference [7], in turn, argue that waste management is emerging as a key sector for sustainable development in South Africa with opportunities for enhancing investments in carbon credits that target reduction of methane from landfills.

Thus, looking for provide a technical tool for solid waste managers it is necessary to develop methodologies and supporting decision making models geared to SWM.

Two of the most used tools for assessing the environmental performance are the indexes and indicators. According to [8], an indicator is a quantitative measure that can typically be used to illustrate and communicate complex phenomena in a simple way, providing a significant clue or making perceptible a trend or phenomenon that is not immediately noted.

The Organization for Economic Cooperation and 
Development (OECD) was the first international organization to develop and publish a set of environmental indicators at the beginning of the 90s. According to the model adopted by this organization, the indicators could be classified as: i) Pressure, which reflect the cause of a phenomenon; ii) State, which quantify the state of some element of the environment; iii) Response, which reflect the reaction to a pressure previously established.

On the other hand, environmental indexes can be defined as a set of aggregated indicators, which provide an overview of phenomena that depend on a large number of variables.

Reference [9] describes the most common method to develop indexes which consists in the following steps: decision of the phenomenon to be studied; selection of indicators which should be based on their relevance, comprehensiveness of the chosen topic and the ease and quality of their data needed to obtain it; study of relationships between indicators; standardization and allocation of weights; and robustness and sensitivity tests which aims to evaluate the applicability and scope of the index.

There are numerous tools to support decision making such as the EPA Models [10]: Waste Reduction Model (WARM), Recycled Content Tool (ReCon), and Durable Goods Calculator (DGC). However, although the concern with sustainable development and environment protection has considerably grown in the last years it is noted that the majority of decision making models and tools are still excessively tied to economic aspects.

In this context, the Industrial Solid Waste Disposal Index (ISWDI) was developed with the objective of enabling an assessment of environmental performance of solid waste management of industries, and support managers in their decision making.

The ISWDI has been determined from real industry data and the results have shown which this index is an excellent tool to the evaluation and management of waste in the industrial sector.

This paper aims to present the mathematical formulation of the ISWDI and apply it to evaluate environmental performance of solid waste management industries of Latin America.

\section{Methodology}

\section{A. ISWDI Description}

The search for greater environmental efficiency in industries depends on a prior knowledge about the intrinsic data from their industrial sector. Thus, the development of an index for solid waste management will allow assessing environmental efficiency and developing strategies that will lead to cleaner production.

The development of the industrial solid waste destination index (ISWDI) takes into account the principles of non-generation, minimization, reuse, recycling, treatment, disposal and waste storage. The ISWDI is formed by indicators grouped into seven sub-indexes: Minimization of Waste Generation (IMR), Reuse (IRR), Recycling (IRC), Co-processing (ICO), Waste Incineration (IIN), Final Disposal (IDF) and Waste Stocked (IES). Their range of variation is from zero to one, and the value of maximum efficiency is one. For the selection and weighting of these indicators an opinion poll based on Delphi method, as detailed by [11], was performed.

From the calculation ISWDI whose outcome can vary between 0 and 1, the industries are classified according to their solid waste management environmental performance. The categories of classification in terms of ISWDI values are presented in Table I.

TABLE I: ISWDI CLASSIFICATION RANGE

\begin{tabular}{|c|c|}
\hline ISWDI Range & Classification \\
\hline 0,9 a 1,0 & EXCELLENT \\
\hline 0,8 a 0,9 & VERY GOOD \\
\hline 0,7 a 0,8 & GOOD \\
\hline 0,6 a 0,7 & REGULAR \\
\hline 0,5 a 0,6 & TOLERABLE \\
\hline 0,4 a 0,5 & BAD \\
\hline$<0,4$ & VERY BAD \\
\hline
\end{tabular}

The methodology used in the development of the ISWDI was based on the guidelines of [12].

\section{B. Mathematical Formulation}

The ISWDI is formed by combination (aggregation) of several indicators $q i$ and each one has a weight wi. Initially, two methods of aggregation were used: Summation and Product model whose mathematical formulations are presented respectively in Eq. (1) and (2). These two methods of aggregation were tested because they have already been adopted in several works dedicated to develop indexes to evaluate water quality and waste management [13]-[15].

$$
\begin{aligned}
& \mathrm{ISWDI}=\sum_{i=1}^{n} w i q i \\
& \mathrm{ISWDI}=\prod_{i=1}^{n} q_{i^{w i}}
\end{aligned}
$$

where: $w i=$ weight given to each indicator whose sum is equal to $1 ; q i=$ indicator value normalized; $i=$ environmental indicator included in the index; $n=$ total number of indicators.

\section{Normalization of Input Data}

The normalization aims to attribute comparability to available data, as they usually have different scales. Firstly, it was intended to use a linear normalization. However, it was realized that this normalization did not match observed reality and did not present satisfactory results in extreme conditions.

Thus, it was observed that the difficulty of the effort made by the company was not contemplated by the indicators. Any effort in the linear model is seen as the same. So we adopted a normalization based on a logarithmic curve. Thus this indicator numerically reward conditions of work with respect to the difficulty faced on a global scale.

The logic is most easily demonstrated by an example: suppose an industry which from a year to another had increased its percentage of recycling of solid waste from $10 \%$ to $20 \%$, improving by 10 percentage points, and another 
industry B in the same sector increased their percentage of reuse from $70 \%$ to $80 \%$ in the same period, improving the same 10 percentage points from the previous. In fact the percentage of improvement was the same for both industries, however, the effort required to achieve an improvement when it is already close to the reference value is much higher, i.e. $\mathrm{B}$ industry has had to commit more than industry A.

In addition, it should be noted that after an analysis of the existing indexes, which have emphasized the same problem, it could be concluded that this model was the ideal for solving the problem just described. Once the appropriate standards for components of the ISWDI indicators were defined, benchmarks were established for each industrial sector studied.

Then these values were normalized by logarithmic curves and added to standardization curves of indicators. Thus, each indicator has its variation range demarcated by the observed reality and therefore it is able to take in account that a industry have better performance if it is near the highest or lowest value observed for the sector in which it fits.

\section{Pre-Defined Indicators}

The indicators that make up the ISWDI, were previously established according to the environmental performance indicators recommended by the international standard ISO 14031 [16] as well as those proposed by [12], [17]-[19]. First of all, 31 indicators were pre-defined and grouped into seven sub-indexes: minimization of waste generation (IMR), reuse (IRR), recycling (IRC), co-incineration in a cement kiln (ICO), incineration (IIN), final disposal (IDF) and storage (IES).

In an attempt to complete the characterization of the indicators proposed in this paper, the model Pressure - State Response, developed by [12], [18] for environmental indicators and internationally accepted, was followed. Among the 31 indicators pre-selected to compose the index ISWDI, seven have characteristics of response indicators and the others 24, of Pressure.

\section{E. Delphi Method and Indicator Weight Attribution}

Among the preselected indicators, an opinion poll by the Delphi Method was carried out so as to define what indicators $q i$ would be used and to establish their weight wi.

Delphi is a research methodology that is characterized by consulting a group of experts with the aim of reaching a consensus on any issue or matter which involves subjective judgments. Briefly, this survey is carried out through questionnaires that are resent until the responses are convergent [11].

For the application of the Delphi Method, a sample of 330 specialists was carefully defined among three target groups: 90 researchers and academics from the solid waste field, 90 technicians from Brazilian Environmental Agencies and 150 professionals from the waste management sector. Table II presents a summary of the panelists according to the target group and region of Brazil.

As recommended by the Delphi method, the research consisted of two steps. In the first stage the questionnaires was sent to respondents, or panelists. Upon receipt of this first round of responses, data were analyzed. In the second stage, the questionnaires were returned to panelists, along with a statistical analysis of early results.

It is highlighted that customized e-mails were sent to each of the panelists holding a letter of presentation of the research proposal and an indicators evaluation form. In that evaluation the panelists were invited to attribute values between 1 and 5 to each indicator according to its importance in the evaluation of environmental performance. It was adopted the following scoring for the indicators: 5 - very important; 4 - important; 3 - relevant; 2 - not relevant; 1 - dispensable.

TABLE II: SUMMARY OF TARGET GROUPS PANELISTS OPINION SURVEY BY BRAZILIAN REGION

\begin{tabular}{|c|c|c|c|c|}
\hline \multirow{2}{*}{$\begin{array}{c}\text { Brazilian } \\
\text { Region }\end{array}$} & \multicolumn{4}{|c|}{ Target Groups Panelists Opinion Survey } \\
\cline { 2 - 5 } & Academics & Technicians & Professionals & $\begin{array}{c}\text { Total of } \\
\text { Panelists }\end{array}$ \\
\hline West-Center & 4 & 7 & 10 & 21 \\
\hline Northeast & 14 & 8 & 4 & 26 \\
\hline North & 5 & 5 & 2 & 12 \\
\hline Southeast & 54 & 61 & 127 & 242 \\
\hline South & 13 & 9 & 7 & 29 \\
\hline TOTAL & 90 & 90 & 150 & 330 \\
\hline
\end{tabular}

From the outcome of Delphi, only the indicators that had mode and average greater than or equal to 4 and the ones that were selected by the three target groups were maintained in the composition of ISWDI. The weights of the indicators, in turn, were defined for each indicator using the cumulative frequency of the mode of the notes 4 and 5 . The weights established by Delphi Method correspond to $50 \%$ of the indicators' weights. The other $50 \%$ was defined according to Brazilian Environmental Laws, specifically on the Environmental State Agency in Minas Gerais State.

\section{F. Benchmark Establishment}

The benchmark that guided the evaluations of Industrial Solid Waste Disposal Index was obtained from environmental reports and auditable documents, as well as technical visits in industries of automotive, pulp and paper, cement, construction, energy, dairy, oil and gas, steel and textiles.

\section{G. Case Study}

To illustrate its application, the index was used to evaluate two industries of Latin America, specifically in the pulp and paper industry, being one from Brazilian and another from Chile. Table III presents the data obtained from the companies surveyed used as input parameters in the calculations of the indicators and ISWDI.

\section{RESUlts AND Discussion}

\section{A. Opinion Pool-Delphi Method}

Three hundred and seven questionnaires, out of 330 posted e-mails, were considered valid because the others 23 included 11 responses from panelists who argued that they were unable to answer the questionnaire and 12 e-mails were sent to incorrect e-mail addresses. This research was carried out during 6 months.

Delphi had a compliance rate of $55.7 \%$ which is closer to the value obtained by [14] who achieved a compliance rate of $57 \%$ to use Delphi to develop an environmental performance 
index. Other environmental studies have presented similar compliance rate: $62 \%$ [20], $51 \%$ [21].

This important contribution is attributed to the quality of the form and the ease to understand and fill it. Table IV presents the number of responses for each target group. Note that the panelists from the academic sector had the highest rate of adherence, probably, due to the fact that they are closer to research projects.

TABLE III: INPUT DATA USED IN ISWDI - PULP AND PAPER INDUSTRIES

\begin{tabular}{|c|c|c|c|c|}
\hline \multirow{2}{*}{$\begin{array}{c}\text { Industrial sector: Pulp and } \\
\text { paper }\end{array}$} & \multicolumn{2}{|c|}{ Brazil } & \multicolumn{2}{c|}{ Chile } \\
\cline { 2 - 5 } & $\mathbf{2 0 1 0}$ & $\mathbf{2 0 1 1}$ & $\mathbf{2 0 1 0}$ & $\mathbf{2 0 1 1}$ \\
\hline Production (tonnes) & $\begin{array}{c}400.3 \\
88\end{array}$ & $\begin{array}{c}465.3 \\
83\end{array}$ & $\begin{array}{c}890.0 \\
00\end{array}$ & $\begin{array}{c}990.0 \\
00\end{array}$ \\
\hline $\begin{array}{c}\text { Amount of total solid waste } \\
\text { generated (tonnes) }\end{array}$ & $\begin{array}{c}217.1 \\
23\end{array}$ & $\begin{array}{c}218.7 \\
32\end{array}$ & $\begin{array}{c}311.3 \\
11\end{array}$ & $\begin{array}{c}273.5 \\
85\end{array}$ \\
\hline $\begin{array}{c}\text { Amount of hazardous waste } \\
\text { generated (tonnes) }\end{array}$ & 129 & 72 & 200 & 150 \\
\hline $\begin{array}{c}\text { Amount of non-hazardous } \\
\text { waste generated (tonnes) }\end{array}$ & $\begin{array}{c}216.9 \\
94\end{array}$ & $\begin{array}{c}218.6 \\
60\end{array}$ & $\begin{array}{c}311.1 \\
11\end{array}$ & $\begin{array}{c}273.4 \\
35\end{array}$ \\
\hline $\begin{array}{c}\text { Amount of total solid waste } \\
\text { reused (tonnes): }\end{array}$ & $\begin{array}{c}28.8 \\
53\end{array}$ & $\begin{array}{c}102.6 \\
90\end{array}$ & $\begin{array}{c}155.5 \\
56\end{array}$ & $\begin{array}{c}177.7 \\
\text { (1) }\end{array}$ \\
\hline $\begin{array}{c}\text { Percentage of non-renewable } \\
\text { fuel save by reuse of solid } \\
\text { waste (\%) }\end{array}$ & - & - & - & - \\
\hline $\begin{array}{c}\text { Percentage of materials save by } \\
\text { reuse of solid waste (\%) }\end{array}$ & - & - & - & - \\
\hline $\begin{array}{c}\text { Percentage of solid waste } \\
\text { transferred to other industry to } \\
\text { be used like materials or fuel } \\
\text { (\%) }\end{array}$ & - & - & - & - \\
\hline $\begin{array}{c}\text { Amount of total solid waste } \\
\text { recycled (tonnes) }\end{array}$ & 63.05 & 97.03 & 31.11 & 82.03 \\
\hline $\begin{array}{c}\text { Percentage of non-renewable } \\
\text { fuel save by recycle of solid } \\
\text { waste (\%) }\end{array}$ & - & - & - & - \\
\hline $\begin{array}{c}\text { Percentage of materials save by } \\
\text { recycle of solid waste (\%) }\end{array}$ & - & - & - & - \\
\hline $\begin{array}{c}\text { Amount of total solid waste } \\
\text { co-incinerated (tonnes) }\end{array}$ & - & - & - & - \\
\hline $\begin{array}{c}\text { Amount of hazardous waste } \\
\text { co-incinerated (tonnes) }\end{array}$ & - & - & - & - \\
\hline $\begin{array}{c}\text { Amount of total solid waste } \\
\text { incinerated (tonnes) }\end{array}$ & - & - & - & - \\
\hline $\begin{array}{c}\text { Amount of hazardous waste } \\
\text { incinerated (tonnes) }\end{array}$ & - & - & - & - \\
\hline $\begin{array}{c}\text { Amount of total solid waste } \\
\text { landfilled (tonnes) }\end{array}$ & 25.21 & 19.00 \\
stored (tonnes) & 9 & 124.4 & 13.67 \\
\hline $\begin{array}{c}\text { Amount of hazardous waste } \\
\text { landfilled (tonnes) }\end{array}$ & 129 & 72 & 200 & 150 \\
\hline $\begin{array}{c}\text { Amount of total solid waste } \\
\text { Amount of hannes) }\end{array}$ & - & - & - & - \\
\hline
\end{tabular}

TABLE IV: DELPHI Results PRESENTEd By TARgEt GRouP

\begin{tabular}{|c|c|c|c|}
\hline Target group & $\begin{array}{c}\text { Valid } \\
\text { emails }\end{array}$ & $\begin{array}{c}\text { Answers } \\
\text { received }\end{array}$ & $\begin{array}{c}\text { Compliance } \\
\text { rate }\end{array}$ \\
\hline Academic & 86 & 52 & $60.5 \%$ \\
\hline Professionals & 141 & 78 & $55.3 \%$ \\
\hline Technicians & 80 & 41 & $51.3 \%$ \\
\hline TOTAL & 307 & 171 & $55.7 \%$ \\
\hline
\end{tabular}

\section{TABLE V: DESCRIPTION OF THE ISWDI INDICATORS SELECTED}

\begin{tabular}{|c|c|}
\hline $\begin{array}{c}\text { Indicator } \\
\text { Code }\end{array}$ & Indicator Description \\
\hline MR-1 & $\begin{array}{c}\text { [total waste generated in the current year (tonnes) / total of } \\
\text { products produced in the current year (tonnes)] / } \\
\text { [total waste generated in the last year (tonnes) / total of products } \\
\text { produced in the last year (tonnes)] }\end{array}$ \\
\hline MR-2 & $\begin{array}{c}{[\text { hazardous waste generated in the current year (tonnes) } / \text { total }} \\
\text { products produced in the current year (tonnes)] } / \\
\text { [hazardous waste generated in the last year (tonnes) / total }\end{array}$ \\
\hline
\end{tabular}

\begin{tabular}{|c|c|}
\hline & products produced in the last year (tonnes)] \\
\hline MR-4 & $\begin{array}{l}\text { [hazardous waste generated in the current year (tonnes) / total } \\
\text { waste generated in the current year (tonnes) ] / } \\
\text { [hazardous waste generated in the last year (tonnes) /total waste } \\
\text { generated in the last year (tonnes)] }\end{array}$ \\
\hline RR-1 & $\begin{array}{c}\text { percentage of waste reused of total of waste generated in the } \\
\text { current year }(\%)\end{array}$ \\
\hline RR-2 & $\begin{array}{l}\text { [waste reused in the current year (tonnes)/total waste generated } \\
\text { in the current year (tonnes)] / } \\
\text { [waste reused in the last year (tonnes)/ total waste generated in } \\
\text { the last year (tonnes)] }\end{array}$ \\
\hline RR-4 & $\begin{array}{l}\text { percentage of non-renewable fuel saved by reuse of solid waste } \\
\text { in the current year }(\%)\end{array}$ \\
\hline RR-5 & $\begin{array}{c}\text { percentage of raw materials saved by reuse of solid waste in the } \\
\text { current year }(\%)\end{array}$ \\
\hline RR-6 & $\begin{array}{c}\text { percentage of solid waste transferred to other industry to be used } \\
\text { as raw material or fuel (\%) }\end{array}$ \\
\hline RC-1 & $\begin{array}{c}\text { percentage of waste recycled of total of waste generated in the } \\
\text { current year }(\%)\end{array}$ \\
\hline RC-2 & $\begin{array}{c}\text { [waste recycled in the current year (tonnes) / total waste } \\
\text { generated in the current year (tonnes)] / } \\
\text { [wastes recycled in the last year (tonnes) / total waste generated } \\
\text { in the last year (tonnes)] }\end{array}$ \\
\hline RC-4 & $\begin{array}{c}\text { percentage of non-renewable fuel save by recycle of solid wastes } \\
\text { in the current year (\%) }\end{array}$ \\
\hline RC-5 & $\begin{array}{c}\text { percentage of raw materials saved by solid waste recycling in } \\
\text { the current year }(\%)\end{array}$ \\
\hline CO-3 & $\begin{array}{l}\text { [waste co-incinerated in the current year (tonnes)/total waste } \\
\text { generated in the current year (tonnes)]/ } \\
\text { [waste co-incinerated in the last year (tonnes) /total waste } \\
\text { generated in the last year (tonnes)] }\end{array}$ \\
\hline $\mathrm{CO}-4$ & $\begin{array}{l}\text { [hazardous waste co-incinerated in the current year } \\
\text { (tonnes)/hazardous waste generated in the current year } \\
\text { (tonnes)]/ } \\
\text { [hazardous waste co-incinerated in the last year (tonnes) / } \\
\text { hazardous waste generated in the last year (tonnes)] }\end{array}$ \\
\hline IN-3 & $\begin{array}{c}\text { [waste incinerated in the current year (tonnes) / total waste } \\
\text { generated in the current year (tonnes)] / } \\
\text { [waste incinerated in the last year (tonnes) / total waste } \\
\text { generated in the last year (tonnes)] }\end{array}$ \\
\hline IN-4 & $\begin{array}{l}\text { [hazardous waste incinerated in the current year } \\
\text { (tonnes)/hazardous waste generated in the current year } \\
\text { (tonnes)]/ } \\
\text { [hazardous waste incinerated in the last year (tonnes) / } \\
\text { hazardous waste generated in the last year (tonnes)] }\end{array}$ \\
\hline DF-3 & $\begin{array}{c}\text { [waste landfilled in the current year (tonnes) / total waste } \\
\text { generated in the current year (tonnes)] / } \\
\text { [waste landfilled in the last year (tonnes)/ total waste generated } \\
\text { in the last year (tonnes)] }\end{array}$ \\
\hline DF-4 & $\begin{array}{c}\text { [hazardous waste landfilled in the current year (tonnes)/ } \\
\text { hazardous waste generated in the current year (tonnes)]/ } \\
\text { [hazardous waste landfilled in the last year (tonnes) / hazardous } \\
\text { waste generated in the last year (tonnes)] }\end{array}$ \\
\hline ES-3 & $\begin{array}{l}\text { [waste stored in the current year (tonnes) / total waste generated } \\
\text { in the current year (tonnes)] / } \\
\text { [waste stored in the last year (tonnes) / total waste generated in } \\
\text { the last year (tonnes)] }\end{array}$ \\
\hline ES-4 & $\begin{array}{l}\text { [hazardous waste stored in the current year (tonnes) / hazardous } \\
\text { waste generated in the current year (tonnes)] / } \\
\text { [hazardous waste stored in the last year (tonnes) / hazardous } \\
\text { waste generated in the last year (tonnes)] }\end{array}$ \\
\hline
\end{tabular}

\begin{tabular}{|c|c|c|c|}
\hline \multicolumn{4}{|c|}{ TABLE VI: ISWDI INDICATORS WEIGHT } \\
\hline Sub-Index & Indicator Code & Weight & $\begin{array}{c}\text { ISWDI } \\
\text { Percentage (\%) }\end{array}$ \\
\hline $\begin{array}{c}\text { Minimizing } \\
\text { (IMR) }\end{array}$ & MR-1 & 0,068 & $\mathbf{1 9 , 6}$ \\
\cline { 2 - 3 } & MR-2 & 0,066 & \\
\hline
\end{tabular}




\begin{tabular}{|c|c|c|c|}
\hline & MR-4 & 0,062 & \\
\hline \multirow[t]{5}{*}{ Reuse (IRR) } & RR-1 & 0,038 & \multirow[t]{5}{*}{17,3} \\
\hline & RR-2 & 0,035 & \\
\hline & RR-4 & 0,033 & \\
\hline & RR-5 & 0,033 & \\
\hline & RR-6 & 0,034 & \\
\hline \multirow[t]{4}{*}{ Recycle (IRC) } & RC-1 & 0,046 & \multirow[t]{4}{*}{16,9} \\
\hline & RC-2 & 0,042 & \\
\hline & RC-4 & 0,039 & \\
\hline & RC-5 & 0,042 & \\
\hline \multirow{2}{*}{$\begin{array}{c}\text { Co-processing } \\
\text { (ICO) }\end{array}$} & $\mathrm{CO}-3$ & 0,058 & \multirow[t]{2}{*}{11,8} \\
\hline & CO-4 & 0,060 & \\
\hline \multirow{2}{*}{$\begin{array}{l}\text { Incineration } \\
\text { (IIN) }\end{array}$} & IN-3 & 0,059 & \multirow[t]{2}{*}{11,7} \\
\hline & IN-4 & 0,058 & \\
\hline \multirow{2}{*}{$\begin{array}{c}\text { Final Disposal } \\
\text { (IDF) }\end{array}$} & DF-3 & 0,062 & \multirow[t]{2}{*}{12,3} \\
\hline & DF-4 & 0,061 & \\
\hline \multirow[t]{2}{*}{ Storage (IES) } & ES-3 & 0,052 & \multirow[t]{2}{*}{10,4} \\
\hline & ES-4 & 0,052 & \\
\hline
\end{tabular}

Table $\mathrm{V}$ presents a description of the selected indicators that make up the ISWDI and Table VI presents the indicators and their weights used in the calculations of ISWDI.

It's noted that the indicators: MR-3, RR-3, RC-3, CO-1,
CO-2, IN-1, IN-2, DF-1, DF-2, ES-1, ES-2 are eliminated according to Delphi results, based on the criteria just described.

\section{B. Case Study Results}

Analyzing Table III it can be seen that in the years 2010 and 2011, the Brazilian Industry reused percentages of 59.4\% and $47.0 \%$, respectively, of their waste generated, while the Chilean paper Industry reused percentage of $50.0 \%$ and $65.0 \%$, respectively.

Concerning the aggregation method, the summation method was chosen because the product model could mask the results because if an industry presents only one bad indicator value it gives a null ISWDI value even if it presents rather good indicator values. That is why product model was not retained to ISWDI simulation; consequently it will apply the summation model that doesn't present this problem.

Tables VII and VIII show the results obtained for calculating the ISWDI by the summation method for Brazilian and Chilean industries respectively.

TABLE VII: ISWDI RESULTS (SUMMATION METHOD) FOR A BRAZILIAN PULP AND PAPER INDUSTRY

\begin{tabular}{|c|c|c|c|c|c|c|}
\hline \multirow{2}{*}{ Indicator } & \multicolumn{2}{|c|}{ Benchmark } & \multirow{2}{*}{$\begin{array}{c}\text { Normal Value } \\
\text { Vnorm }\end{array}$} & \multirow{2}{*}{$\begin{array}{c}\text { Indicator } \\
\text { Weight }\end{array}$} & \multirow{2}{*}{$\begin{array}{c}\text { Sub-index } \\
\text { Total }\end{array}$} & \multirow{2}{*}{$\begin{array}{c}\text { Index Value } \\
\text { ISWDI }\end{array}$} \\
\hline & Vmin & Vmax & & & & \\
\hline MR-1 & 0,0022 & 0,7895 & 0,06 & 0,068 & \multirow{3}{*}{$\mathrm{IMR}=0,066$} & \multirow{21}{*}{0,411} \\
\hline MR-2 & 0,0000 & 0,5783 & 0,52 & 0,066 & & \\
\hline MR-4 & 0,0003 & 0,4458 & 0,45 & 0,062 & & \\
\hline RR-1 & 0,0355 & 0,2919 & 0,05 & 0,038 & \multirow{5}{*}{$\mathrm{IRR}=-0,013$} & \\
\hline RR-2 & 0,0075 & 0,4743 & $-0,43$ & 0,035 & & \\
\hline RR-4 & 0,0000 & 1,0000 & 0,00 & 0,033 & & \\
\hline RR-5 & 0,0000 & 1,0000 & 0,00 & 0,033 & & \\
\hline RR-6 & 0,0000 & 1,0000 & 0,00 & 0,034 & & \\
\hline $\mathrm{RC}-1$ & 0,0069 & 0,3406 & 0,21 & 0,046 & \multirow{4}{*}{$\mathrm{IRC}=0,016$} & \\
\hline $\mathrm{RC}-2$ & 0,0006 & 0,9519 & 0,16 & 0,042 & & \\
\hline $\mathrm{RC}-4$ & 0,0000 & 1,0000 & 0,00 & 0,039 & & \\
\hline $\mathrm{RC}-5$ & 0,0000 & 1,0000 & 0,00 & 0,042 & & \\
\hline $\mathrm{CO}-3$ & 0,1010 & 0,5294 & 1,00 & 0,058 & \multirow{2}{*}{$\mathrm{ICO}=0,118$} & \\
\hline $\mathrm{CO}-4$ & 0,0000 & 1,0000 & 1,00 & 0,060 & & \\
\hline IN-3 & 0,0624 & 0,9253 & 1,00 & 0,059 & \multirow{2}{*}{$\mathrm{IIN}=0,117$} & \\
\hline IN-4 & 0,0001 & 0,5229 & 1,00 & 0,058 & & \\
\hline DF-3 & 0,0054 & 0,3138 & 0,04 & 0,062 & \multirow{2}{*}{0,002} & \\
\hline $\mathrm{DF}-4$ & 0,0366 & 0,6350 & 0,00 & 0,061 & & \\
\hline ES-3 & 0,0001 & 0,8669 & 1,00 & 0,052 & \multirow{2}{*}{0,104} & \\
\hline \multirow[t]{2}{*}{ ES-4 } & 0,0000 & 1,0000 & 1,00 & 0,052 & & \\
\hline & & & TOTAL & 1,0 & & \\
\hline
\end{tabular}

Observing the data in Table VIII, it is seen that for 2010 and 2011 the production of Chilean pulp and paper industry was greater than twice that the one from Brazil.

Nevertheless, the difference in waste generation was not so significant, reaching $43.4 \%$ and $25.1 \%$ in 2010 and 2011 respectively. It is noted that the disposal method of most part of waste is similar: about $90 \%$ are reused in both industries.

The destination of the remaining non-hazardous waste generated is also similar between them, divided between recycling and landfilling. It was also observed that for both industries evaluated hazardous waste were sent to landfill.

Furthermore, the data in Table VII show that there was a great improvement in the environmental performance of Brazilian industry. While production increase $16.2 \%$, waste generation increased by only $0.7 \%$. In the Chilean case, the improvement in environmental efficiency was much more significant than the Brazilian. Production increased (11.2\%), while waste generation decreased by $12.1 \%$.

The Tables VII and VIII show how to calculate the ISWDI by the summation method reflected the improvement in production management and industrial solid waste, especially in the Chilean case. Indeed, while the Chilean industry obtained an ISWDI equal to 0.426 (range of "bad" label), slightly higher than the result of Brazil, which reached 0.411 (range of "bad" label). 
TABLE VIII: ISWDI RESULTS (SUMMATION METHOD) FOR A CHILEAN PULP AND PAPER INDUSTRY

\begin{tabular}{|c|c|c|c|c|c|c|}
\hline \multirow{2}{*}{ Indicator } & \multicolumn{2}{|c|}{ Benchmark } & \multirow{2}{*}{$\begin{array}{c}\text { Normal Value } \\
\text { Vnorm } \\
\end{array}$} & \multirow{2}{*}{$\begin{array}{c}\text { Indicator } \\
\text { Weight }\end{array}$} & \multirow{2}{*}{$\begin{array}{l}\text { Sub-index } \\
\text { Total }\end{array}$} & \multirow{2}{*}{$\begin{array}{l}\text { Index Value } \\
\text { ISWDI }\end{array}$} \\
\hline & Vmin & Vmax & & & & \\
\hline MR-1 & 0,0022 & 0,7895 & 0,13 & 0,068 & \multirow{3}{*}{$\mathrm{IMR}=0,066$} & \multirow{21}{*}{0,426} \\
\hline MR-2 & 0,0000 & 0,5783 & 0,28 & 0,066 & & \\
\hline MR-4 & 0,0003 & 0,4458 & 0,15 & 0,062 & & \\
\hline RR-1 & 0,0355 & 0,2919 & 0,25 & 0,038 & \multirow{5}{*}{$\mathrm{IRR}=-0,013$} & \\
\hline RR-2 & 0,0075 & 0,4743 & 0,14 & 0,035 & & \\
\hline RR-4 & 0,0000 & 1,0000 & 0,00 & 0,033 & & \\
\hline RR-5 & 0,0000 & 1,0000 & 0,00 & 0,033 & & \\
\hline RR-6 & 0,0000 & 1,0000 & 0,00 & 0,034 & & \\
\hline $\mathrm{RC}-1$ & 0,0069 & 0,3406 & 0,09 & 0,046 & \multirow{4}{*}{$\mathrm{IRC}=0,016$} & \\
\hline $\mathrm{RC}-2$ & 0,0006 & 0,9519 & 0,20 & 0,042 & & \\
\hline RC-4 & 0,0000 & 1,0000 & 0,00 & 0,039 & & \\
\hline RC-5 & 0,0000 & 1,0000 & 0,00 & 0,042 & & \\
\hline $\mathrm{CO}-3$ & 0,1010 & 0,5294 & 1,00 & 0,058 & \multirow{2}{*}{$\mathrm{ICO}=0,118$} & \\
\hline $\mathrm{CO}-4$ & 0,0000 & 1,0000 & 1,00 & 0,060 & & \\
\hline IN-3 & 0,0624 & 0,9253 & 1,00 & 0,059 & \multirow{2}{*}{$\mathrm{IIN}=0,117$} & \\
\hline IN-4 & 0,0001 & 0,5229 & 1,00 & 0,058 & & \\
\hline DF-3 & 0,0054 & 0,3138 & 0,38 & 0,062 & \multirow{2}{*}{$\mathrm{IDF}=0,002$} & \\
\hline DF-4 & 0,0366 & 0,6350 & 0,00 & 0,061 & & \\
\hline ES-3 & 0,0001 & 0,8669 & 1,00 & 0,052 & \multirow{2}{*}{$\mathrm{IES}=0,104$} & \\
\hline \multirow[t]{2}{*}{ ES-4 } & 0,0000 & 1,0000 & 1,00 & 0,052 & & \\
\hline & & & TOTAL & 1,0 & & \\
\hline
\end{tabular}

\section{CONCLUSION}

Analyzing the results, it was found that the Industrial Solid Waste Disposal Index (ISWDI) is a tool that reflects numerically qualities and faults of an industrial waste management system, enabling the identification of problems. Moreover, the use of this tool in industries was checked efficiently for the case of Latin American ones.

The numerical values obtained for Summation method demonstrate the real situation of the environmental performance in terms of solid waste management in the industrial environment, highlighting the applicability of the index. So, the ISWDI could be used as a guide to improve waste management because its results show a quantitative overview of industrial environmental performance.

\section{REFERENCES}

[1] World Bank, What a Waste: a Global Review of Solid Waste Management, Washington DC, USA: World Bank, 2012, ch. 3, pp. 7-8.

[2] R. C. Szaro, W. T. Sexton, and C. R. Malone, "The emergence of ecosystem management as a tool for meeting people's needs and sustaining ecosystems," Landscape and Urban Planning, vol. 40, pp. 1-7, March 1998

[3] A. Orhan, "Eco-economy in sustainable development and waste exchange, a new approach regarding waste management," Middle East Finance and Economics, vol. 10, pp. 41-50, 2011.

[4] World Commission on Environment and Development - WCED, Our Common Future, 2nd ed. Oxford, U.K.: Oxford University Press, 1991, pp. $50-100$.

[5] United States Environmental Protection Agency - USEPA. (April 2012). Municipal Solid Waste. [Online]. Available: http://www.epa.gov/epawaste/nonhaz/municipal/index.htm

[6] J. Giegrich and R. Vogt, "The contribution of waste management to sustainable development in Germany - section on municipal waste," Federal Environment Ministry and Federal Environmental Agency, 2002, pp.15-28.

[7] P. Karani and S. M. Jewasikiewitz, "Waste management and sustainable development in South Africa," Environment, Development and Sustainability, vol.9, May 2006, pp. 163-185.

[8] European Environment Agency - EEA, EEA Core Set of Indicators Guide, Copenhagen, Dnemark: EEA, 2005, pp. 8-12.
[9] M. Saisana and S. Tarantola, "State-of-the-art report on current methodologies and practices for composite indicator development," European Commission-Joint Research Centre, 2002, pp. 23-45.

[10] United States Environmental Protection Agency - USEPA., Solid Waste Management and Green House Gases - A Life cycle Assessment of Emissions and Sinks, 2nd ed. US: EPA, 2006, pp. 45-63.

[11] H. A. Lindstone and M. Turoff. (November 2002). The Delphi Method: Techniques and Applications. [Online]. Available: http://www. is.njit.edu/pubs/delphibook.

[12] Organization for Economic Co-Operation and Development - OECD, Handbook on Constructing Composite Indicators: Methodology and User Guide, Paris, France: OECD, 2008, pp. 83-122.

[13] J. M. Landwehr and R. A. Deininger, "A comparison of several water quality indexes," Journal of Water Pollution Control Federation, vol. 48, no. 5, pp. 954-958, May 1976.

[14] J. C. J. Ribeiro, "Development of a model to assess environmental policies performance. case study: minas gerais state," Ph.D. dissertation, Dept. Environmental Engineering, School of Engineering, Federal University of Minas Gerais (UFMG), Belo Horizonte, Brazil, 2005.

[15] M. E. T. A. Souza and M. Libânio, "Proposal of a raw water quality index influent to conventional water treatment plants," Revista de Engenharia Sanitária e Ambiental, vol. 14, pp. 471-478, October 2009.

[16] Environmental Performance Assessment - Guide, ABNT Standard NBR ISO-14031-2004.

[17] Global Reporting Initiative - GRI, Guide for Sustainability Report, Version 3.0 (Portuguese), São Paulo, Brazil: GRI, 2006, pp. 10-47.

[18] Organization for Economic Co-Operation and Development - OECD, Key Environmental Indicators, Paris, France: OECD, 2001, pp. 11-37.

[19] United Nations Environment Programme - UNEP, Environmental Indicators for North America, ch. 1, Washington DC, USA: United Nations Environment Programme, 2006, pp. 1-22.

[20] W. Joos, V. Carabias, H. Winistoerfer, and A. Stuecheli, "Social aspects of public waste management in Switzerland," Waste Management, vol. 19, pp. 417-425, October 1999.

[21] Y. J. Huang and S. L. Lo, "Construction of social and economical criteria and indicators of forest ecosystem management in Taiwan," in Proc. XXII IUFRO World Congress, Brisbane, Australia: IUFRO, 2005, pp. 251-263.

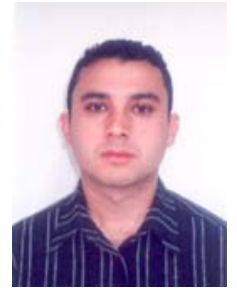

Hosmanny Mauro Goulart Coelho was born in Brazil in 1979. He received his bachelor degree in civil engineering in 2002 and He received his master doctoral and He received his pos-doctoral of science degree in sanitation, environmental and water resources from Federal University of Minas Gerais (UFMG). He also has a MBA in project management (2007) from Getulio Vargas Foundation (FGV) and he is a specialist in alternative forms of energy (2007) 
from Federal University of Lavras (UFLA). Hosmanny has experience in environmental projects of different segments such as construction, sanitation, mining, government, technology and research. He has expertise in environmental engineering, including municipal solid waste and hazardous waste management, sanitary and industrial landfill design, wastewater collection and treatment plants, wastewater pump stations, industrial effluents, transport of contaminants, alternative forms of energy, environmental license process and environmental management.

$\mathrm{He}$ is a lecturer in graduation courses in Brazil and he is the author and co-author of more than twenty technical papers, four book chapters and one book. He has been participated and presented several technical papers in Conferences and Workshops, in Brazil, Latin America, Europe and in the USA. Now, Hosmanny develop research about industrial and municipal solid waste management.

Dr. Coelho is a member of the Brazilian Association of Sanitary and Environmental Engineering (ABES). Hosmanny participated of the SIGERS/UFMG Group of Research, associated to the Program of Research in Sanitation (PROSAB) of the Brazilian Science and Technology Ministry from 2001 to 2005 .

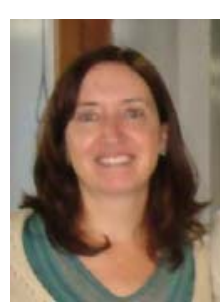

Liséte Celina Lange was born in Brazil and she has a bachelor degree in chemistry from Federal University of Parana, Brazil (1987). She has a master and a doctoral degree in environmental technology from the University of London $(1992,1997)$ in England and a post-doctoral degree from Federal University of Minas Gerais (1999) in Brazil. She has worked in the following areas: 1) industrial waste: characterization, treatment and recycling of industrial solid waste with emphasis on electronic waste and industrial effluen treatment. 2) Municipal waste: Development of processes for treating leachate from landfills, technologies for the treatment of waste, landfill construction processes for small communities, studies of perception of different actors in the field of waste management.

She is a professor at Federal University of Minas Gerais, Belo Horizonte, Brazil at the Environmental and Sanitation Engineering Dept. Now she manages several research projects in the field of waste management, wastewater treatment, environmental engineering and environmental technology. Lange also coordinate the research group SIGERS since 2001. She also coordinates several multidisciplinary projects, and from 2011 to 2014 she was the national coordinator of the research network in leachate treatment, a project funded by FINEP and CNPq. In the period from 02/1013 to $30 / 05 / 2014$ Lange was the coordinator of the Technical Board of Engineering and Architecture of the Foundation for Research Support of Minas Gerais (FAPEMIG)
Dr. Lange is a member of the Brazilian Association of Sanitary and Environmental Engineering (ABES) and of the International Solid Waste Association (ISWA).

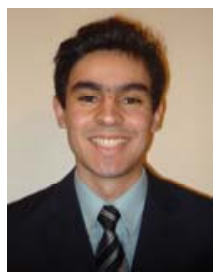

Lineker Max Goulart Coelho was born in Brazil in 1987. He has a bachelor degree in civil engineering and a master professional degree in Structural engineering from Federal University de Minas Gerais, Brazil $(2011,2014)$. He also has a bachelor degree in environmental engineering and a Master of science degree in environmental and sanitation engineering from Ecole des Ponts Paristech, France (2010, 2011) and a MBA degree from ENPC School of International Management, France (2011). Lineker works in engineering projects and research in the following fields: environmental protection, solid waste management, water and wastewater treatment, water supply, computational fluid dynamics, structural analysis and structural dynamics.

$\mathrm{He}$ is a lecturer in graduation courses at Federal University of Viçosa in Brazil. He had worked in the design of industrial projects to mining industries and to the oil and gas sector. He had participated and presented several technical papers in Conferences in Brazil and Europe.

Mr. Coelho participated of the SIGERS/UFMG Group of Research, associated to the Program of Research in Sanitation (PROSAB) of the Brazilian Science and Technology Ministry from 2008 to 2009

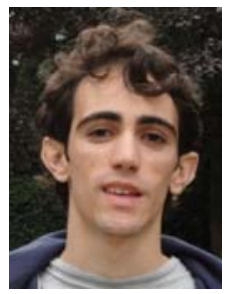

Matheus Rennó Sartori was born in Brazil in 1990 he is an undergraduate in civil engineering at Federal University of Minas Gerais (Brazil) and an undergraduate in City/Urban, Community and Regional Planning engineer degree at Ecole des Ponts Paristech (France). He had carried out researches on several projects related to solid waste management and environmental technology.

$\mathrm{He}$ is nowadays a intern researcher in a project of vironmental index development. Sartori had participated of a research oject related to the development of indicators to assess solid waste anagement funded by CNPQ.

Sartori was a member of the SIGERS/UFMG Group of Research from $110-2012$ 